\title{
Characteristics of Soil Suction with Filter Paper Test Method
}

\author{
Yulindasari Sutejo ${ }^{\#}$, Anis Saggaff ${ }^{\#}$, Wiwik Rahayu ${ }^{*}$, Hanafiah $^{\#}$ \\ ${ }^{\#}$ Civil Engineering Department, Faculty of Engineering, Universitas Sriwijaya, Inderalaya, 30139, Indonesia \\ E-mail: yulindasari@unsri.ac.id, anissaggaf@yahoo.com(corresponding author),hanafiah_dr@yahoo.com.sg \\ *Civil Engineering Department, Faculty of Engineering, Universitas Indonesia, Depok, Indonesia \\ E-mail:wrahayu@eng.ui.ac.id
}

\begin{abstract}
Soil suction is the ability of the soil to absorb water. Type of soil in this research was peat soil and clay soil. The soil samples had been used were taken from Village III Banyu Urip, Banyuasin Regency, South Sumatera Province. Laboratory testing with Filter Paper test method. The filter paper used is Whatman Filter Paper No.42. The Scanning Electron Microscope (SEM) had been used to analyze the orientation of fiber content. Energy Dispersive Spectroscopy (EDS) also to analyze the chemical elements. Characteristics of peat soil are water content value $(\omega)$ is $294.30 \%$, acidity $(\mathrm{pH})$ value is 3.000 , and peat soils classified as fibrous peat soils. While the characteristics of clay soil are water content value is $(\omega) 62.05 \%$, acidity $(\mathrm{pH})$ value is 5.000, and clay soils classified as A-7-5 (AASHTO) and OH (organic clay) based on USCS. The result of the test paper filter test on peat soil obtained from the value of suction is $(\Psi) 3.2432 \mathrm{kPa}-17.5230 \mathrm{kPa}$. The results of testing the Filter Paper test method on the clay obtained the value of suction is ( $\Psi) 61.8733 \mathrm{kPa}-100.3421 \mathrm{kPa}$. The value of suction from clay soil is more than a value of suction peat soil based on Filter Paper test method.
\end{abstract}

Keywords - soil suction; peat soil; clay soil; filter paper; characteristics soil.

\section{INTRODUCTION}

South Sumatra Province has a soil type with varying conditions such as peat and clay soil. Peat soil is a mixture of organic fragments derived from vegetation that has been transformed into fossils chemically. Clay soil is a mineral particle with fine grain size and has the potential for shrinkage. The characteristic of peat soil containing water content is quite high, causing peat soil to have a low of suction soil. The soil suction is directly connected with the released energy in the pores of water content in the soil. Based on clay soil characteristics influenced by moisture content it also affects the occurrence of soil suction on clay soil. The higher the groundwater content, the soil suction ability will be lower.

Soil suction is the capability of the soil to absorb water. Therefore, to determine the value of soil suction done laboratory testing by testing the soil suction. There are several methods to measure soil suction in the laboratory, among others tensiometer, thermal conductivity, and filter paper. In this research, laboratory testing is done using a filter paper method. Filter paper method is a simple test method whose main media is a filter paper by measuring the water content of filter paper. The filter paper used in this research is Whatman filter paper No. 42 [1] - [5]. Research from [2] using the filter paper method. This method is used to analyze suction matrix suction and total suction. The results show higher water content in the compacted soil.

The relationship between water content and soil suction is the definition of the Soil Water Characteristic Curve. Water content states the amount of water contained in the pores of the soil. Some critical parameters in SWCC are Air Entry Value (AEV), slope curve function for negative or positive pore water pressure $(\mathrm{MW})$, and residual water content $(\theta \mathrm{v})$ or saturation (Sr). Soil Water Characteristic Curve (SWCC) is used as an estimate or estimate of soil properties in measuring its suction [3], [6]-[8]. The specific of Soil Water Characteristic Curve (SWCC) can be seen in Fig. 1 [6].

Reference [3] analyzes the effect of the Soil Water Characteristic Curve (SWCC) on kaolin samples. The kaolin sample had been used in the compacted condition. Based on the test it is found that density value and initial water content value influence to SWCC characteristics. [7] stated that the Soil Water Characteristic Curve (SWCC) affects the characteristics of unsaturated soil conditions. Parameters such as residual water content, Air Entry Value (AEV), and slope of the graph affect SWCC analysis. A simple method to estimate the Soil Water Characteristic Curve (SWCC) is examined by [8]. Soil types used are fine-grained soils and coarse-grained soils. The result of the research shows that data analysis using the simple method used is better than the one point method. 


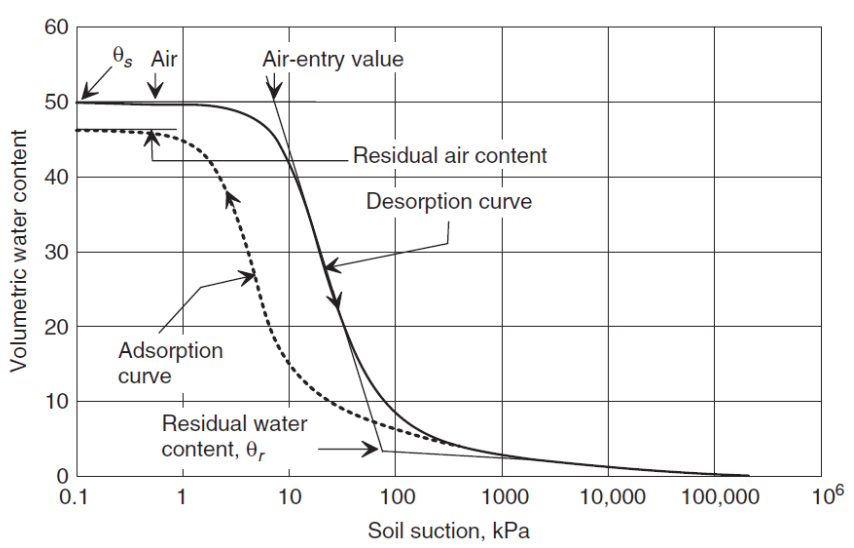

Fig. 1 SWCC characteristic [6]

\section{MATERIAL AND METHOD}

The research methodology used is the laboratory testing method conducted in Soil Mechanics Laboratory of Civil Engineering Department of Sriwijaya University. This research started with a survey of the research location. The location of the soil sampling is in Banyuasin District, South Sumatra Province. Soil samples taken are peat and clay soil. Soil sampling is undertaken in disturbed and undisturbed condition. Before testing the ability of peat soil and clay soil of the filter paper method, first testing soil properties.

Soil properties testing of peat soil are: (1) water content ( $\square$ ) ASTM D 2974-87; (2) acidity of peat soil (pH) ASTM D 2976-71; (3) specific gravity (Gs) ASTM D 854-14; (4) fiber content (FC) ASTM D 1997-13; and (5) organic content (OC) and ash content (AC) ASTM D 2974-14. While the testing of soil properties for clay soil is consists of several tests, among others: (1) water content, ASTM D 2216; (2) Specific Gravity, (Gs) ASTM D 854; (3) Sieve Analysis, ASTM D 422; and (4) Atterberg Limits ASTM D4318. Soil classification using a soil classification system based on AASHTO (American Association of States Highway and Transportation Official) and USCS (Unified Soil Classification System).

Soil suction testing for peat soil and clay soil in this research using measurement techniques with filter paper test methods. Soil suction testing using the filter paper method is based on ASTM D 5298-03. The filter paper used is Type II Whatman No. 42. The filter paper used in this research is shown in Fig. 2.

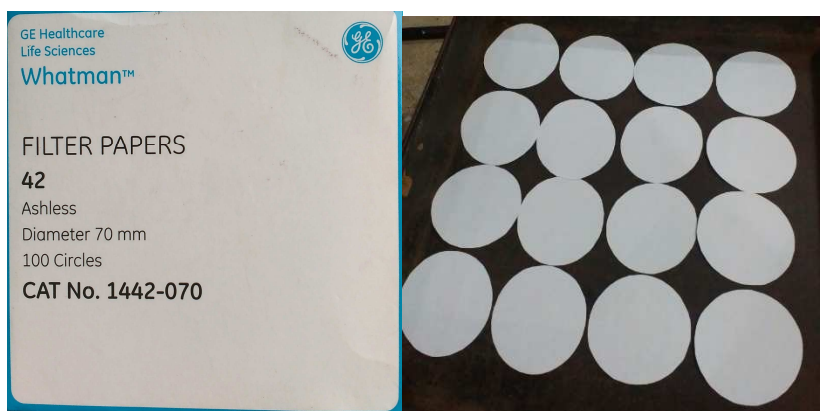

Fig. 2 Filter paper Whatman no.42

After peat soil sampling and soil properties, soil testing, then proceed with the preparation of making a sample of the specimen. The making of this specimen was done in Soil
Mechanics Laboratory of Civil Engineering Department of Sriwijaya University. Using a piece of pipe measuring 57 $\mathrm{mm}$ in diameter and about $50 \mathrm{~mm}$ in height, the soil sample used was compacted on the compacted pipe. In this research, we used two pieces of pipe mold soil samples. The soil mold of each piece of pipe will be used as a sample of the test material for soil suction measurement. At least more than two pieces of pipe are required to print the soil sample to be used in the soil suction test. In the peat soil and clay soil measurement test using the filter paper method, six samples were used as a sample of the suction test. Research from [2] had been used compacted samples with height (h) $70 \mathrm{~mm}$ and internal diameter (d) $85 \mathrm{~mm}$ for the filter paper test method.

The data obtained from the test results are data soil properties (soil characteristics), data of soil test suction with a filter paper method, and water content data every seven days. Soil suction test obtained data weight of dry filter paper and water in filter paper. From the data obtained value of filter paper water content. The soil suction value was obtained by calibrating the moisture content of the ASTM standard Whatman filter paper 42. From the data of the water content can be obtained the value of a degree of saturation $(\mathrm{Sr}, \%)$ and volumetric water content $(\Theta \mathrm{v}, \%)$. In soil suction testing that has been done can be known Soil Water Characteristic Curve (SWCC) which describes the relationship of soil water with moisture content $(\square)$, a degree of saturation $(\mathrm{Sr})$, and volumetric water content $(\Theta v)$.

\section{RESUlTS AND DISCUSSION}

The type of soil had been taken was peat soil and clay soil. Soil properties testing has been done on this soil samples. The test was conducted at Soil Mechanics Laboratory of Civil Engineering Department of Sriwijaya University. The results of the laboratory tests are shown in Table 1 and Table 2. The water content $(\omega)$ from peat soil in Table 1 is $294.30 \%$. The acidity $(\mathrm{pH})$ value of peat soil samples obtained from field testing is 3.00 and from laboratory testing is 3.16. The $\mathrm{pH}$ results indicate that the peat soils contain high levels of acid and are included in the category of highly acidic. Based on the Von Post classification, peat soils are included on the $\mathrm{H} 4$ scale where peat soils decay slightly and emit dark and very turbid water. So that the characteristics of peat soil from Village III Banyu Urip, Banyuasin regency are included in the type of fibrous peat soil. The characteristics of peat soil in Ogan Ilir Regency, South Sumatera Province were also classified as fibrous peat soil. The value of water content $(\square)$ in the range $409.09 \%$ 493.01\% [9]. Based on the results from [10], the value of acidity $(\mathrm{pH})$ of peat soil which is taken from Indah Kiat Pulp and Paper, Perawang, Riau Province is 3.20.

The value of water content in clay soil (Table 2) from Village III Banyu Urip, Banyuasin regency in the amount of to $62.05 \%$. Based on testing the degree of acidity $(\mathrm{pH})$ obtained $\mathrm{pH}$ value of 5.00. Classification of clay soils based on AASHTO to the classification in A-7-5. Based on the AASHTO soil classification system, it is known that soil samples are more than $35 \%$ of the grained soil sieve pass No. 200. So it is categorized as a clay soil with the level of general rating as subgrade fair to weak. While based on USCS obtained the liquid limit value of more than $50 \%$ and 
percentage of grains passed 200 more than $50 \%$ sieve. So the soil including the classification of $\mathrm{OH}$ (organic clay with moderate to high plasticity).

TABLE I

Characteristics of PeAt SoIL

\begin{tabular}{|c|l|l|}
\hline No. & \multicolumn{1}{|c|}{ Tests } & Results \\
\hline 1. & Water Content $(\omega, \%)$ & 294.300 \\
\hline 2. & Specific Gravity $\left(\mathrm{G}_{\mathrm{s}}\right)$ & 1.799 \\
\hline 3. & Acidity $(\mathrm{pH})$ & 3.160 \\
\hline 4. & Organic Content $(\mathrm{OC}, \%)$ & 77.400 \\
\hline 5. & Ash Content $(\mathrm{AC}, \%)$ & 26.610 \\
\hline 6. & Fiber Content $(\mathrm{FC}, \%)$ & 70.450 \\
\hline 7. & Void Ratio $(\mathrm{e})$ & 3.092 \\
\hline 8. & Wet Unit Weight $\left(\gamma_{\mathrm{b}}, \mathrm{kN} / \mathrm{m}^{3}\right)$ & 17.335 \\
\hline 9. & Dry Unit Weight $\left(\gamma_{\mathrm{d}}, \mathrm{kN} / \mathrm{m}^{3}\right)$ & 4.396 \\
\hline 10. & Cohesion $(\mathrm{c}, \mathrm{kPa})$ & 7.649 \\
\hline 11. & Internal Friction $\left(\phi,{ }^{\circ}\right)$ & 24.000 \\
\hline 12. & Shear Strength $(\tau, \mathrm{kPa})$ & 8.720 \\
\hline 13. & Von Post Scale & $\mathrm{H}_{4}$ \\
\hline
\end{tabular}

TABLE II

CHARACTERISTICS OF CLAY SOIL

\begin{tabular}{|c|l|l|}
\hline No. & \multicolumn{1}{|c|}{ Tests } & Results \\
\hline 1. & Water Content $(\omega, \%)$ & 62.050 \\
\hline 2. & Specific Gravity $\left(\mathrm{G}_{\mathrm{s}}\right)$ & 2.594 \\
\hline $3 .$. & Liquid Limit $(\mathrm{LL}, \%)$ & 65.200 \\
\hline 4. & Plastic Limit $(\mathrm{PL}, \%)$ & 42.870 \\
\hline 5. & Index plastic $(\mathrm{IP}, \%)$ & 22.330 \\
\hline 6. & Wet Unit Weight $\left(\gamma_{\mathrm{b}}, \mathrm{kN} / \mathrm{m}^{3}\right)$ & 17.531 \\
\hline 7. & Dry Unit Weight $\left(\gamma_{\mathrm{d}}, \mathrm{kN} / \mathrm{m}^{3}\right)$ & 10.818 \\
\hline 8. & Void Ratio $(\mathrm{e})$ & 1.396 \\
\hline 9. & Acidity $(\mathrm{pH})$ & 5.000 \\
\hline 10. & Cohesion $(\mathrm{c}, \mathrm{kPa})$ & 18.000 \\
\hline 11. & Internal Friction $\left(\phi,{ }^{\circ}\right)$ & 22.835 \\
\hline 12. & Shear Strength $(\tau, \mathrm{kPa})$ & 26.521 \\
\hline 13. & Classification AASHTO & $\mathrm{A}-7-5$ \\
\hline 14. & Classification USCS & $\mathrm{OH}$ \\
\hline
\end{tabular}

The fiber content can be examined under a Scanning Electron Microscope (SEM). Fig. 3 and Fig. 4 shows the typical fiber orientation obtained by Scanning Electron Microscope (SEM) for soil obtained from Village III Banyu Urip, Banyuasin, South Sumatra Province. Based on test results conducted on the SEM peat in the Chemical Laboratory of Chemical Engineering Department of the Sriwijaya Polytechnic visible pores and fibers contained. The sample used in this test was a sample which is cut horizontally with a magnification up to $10.000 x$.

Testing of EDS (Energy Dispersive Spectroscopy) also performed for peat soil and clay soil sample from Village III Banyu Urip, Banyuasin, South Sumatra Province. EDS test was done to analyze the chemical elements contained in the peat soil and clay soil. The results of the testing of EDS can be seen in Fig. 5 and Fig. 6. Research [11] reported the results from a Scanning Electron Microscope (SEM) and Energy Dispersive Spectroscopy (EDS) tests. Based on the results of the EDS test showed that element $\mathrm{C}$ has the highest content.

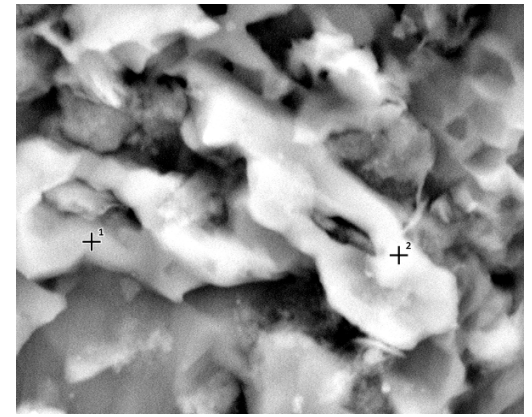

Fig. 3 Result of sem 10000x peat soil sample in village iii banyu urip, banyuasin regency

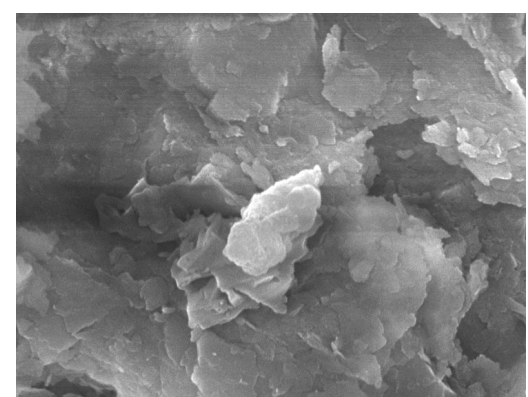

Fig. 4 Result of sem 10000x clay soil sample in Village iii banyu urip, banyuasin regency

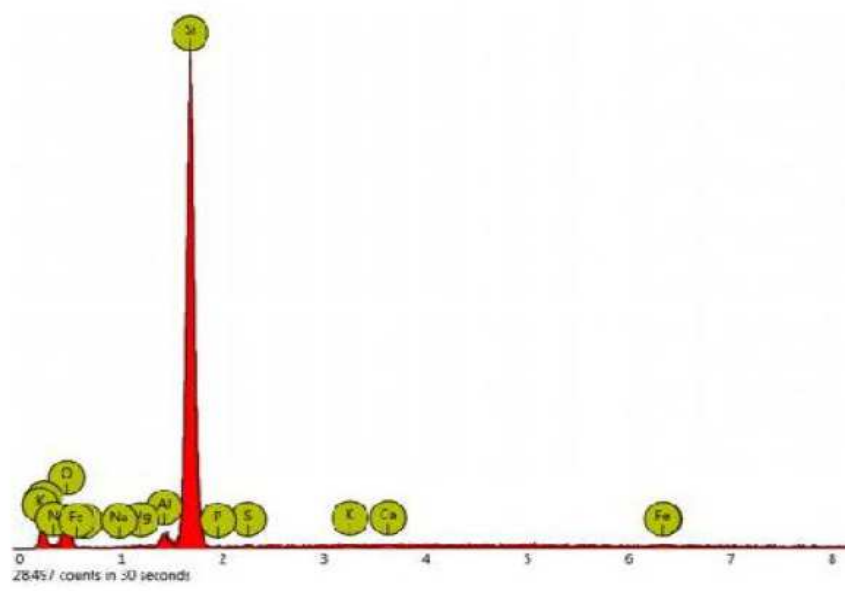

Fig. 5 Result of eds from peat soil in Village iii banyu urip, banyuasin regency

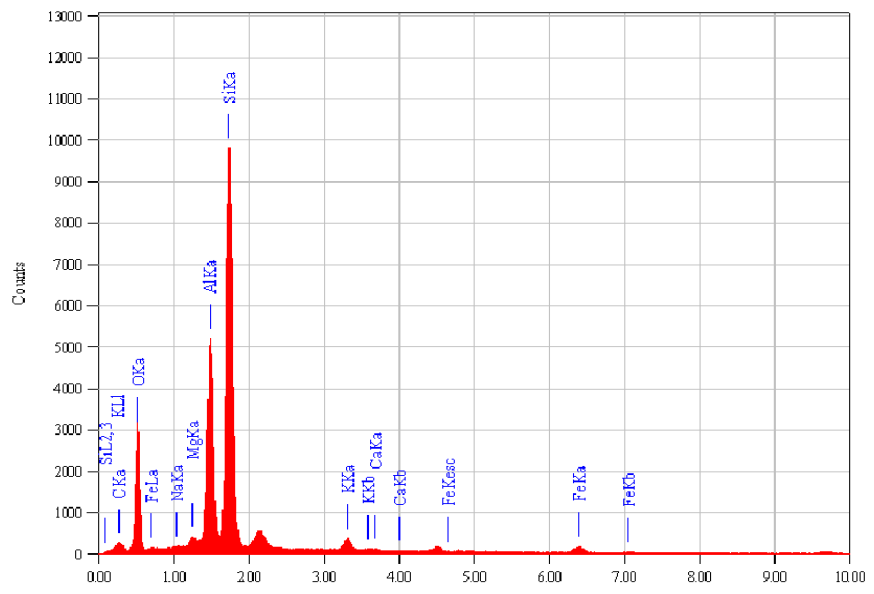

Fig. 6 Result of eds from soil sample in village iii banyu urip, banyuasin regency 
Soil suction testing using filter paper method on clay soil and peat soil from Village III Banyu Urip, Banyuasin regency had been done at Soil Mechanics Laboratory of Civil Engineering Department of Sriwijaya University based in ASTMD5298-03. Soil suction tests conducted as many as six samples on peat soil and clay soils. In this research, the soil suction value was obtained from the amount of water content on the Filter Paper calibrated by using a calibration curve or with an equation for Whatman Filter Paper No. 42.

Table 3 shows the peat soil peat result from P1 sample testing. Table 4 shows the clay soil result from $\mathrm{C} 1$ sample testing. Based on Table 3, peat soil under the Degree of Saturation (Sr) condition is $100 \%$ obtained water content $(\square)$ $149.4095 \%$, Volumetric of water content ( $(\mathrm{vv}) 85.3882 \%$,

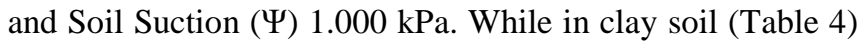
for Degree of Saturation (Sr) of $97.7485 \%$ obtained water content $(\square) 42.5407 \%$, Volumetric of water content ( $\square v$ )

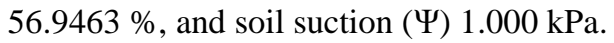

The result of soil suction in Table 3 and Table 4 can be seen that the change of the suction value occurring on the peat and clay soils is related to the value of water content and the degree of saturation possessed by soil samples. The relationship of moisture content, a degree of saturation, and volumetric water content with soil suction occurring on peat soil samples can be seen in Fig. 7, Fig. 8, and Fig. 9. While Fig. 10, Fig. 11, and Fig. 12 shows the relationship of moisture content, a degree of saturation, and volumetric water content with suction on clay soil.

The graph of the relationship between water content $(\square)$ peat soil and soil s suction value as shown in Fig. 7 shows some points of initial value of soil sucking test, AEV value point, and residual water content. From the figure results the soil suction $\Psi=1,000 \mathrm{kPa}$ with $\square=149.4095 \%$ as the initial value of soil suction test, $\Psi 1=6,632632 \mathrm{kPa}$ with $\square 1$ $=127.0030 \%$ as the AEV value, and $\Psi 2=16.7062 \mathrm{kPa}$ with $\square 2=87.9751 \%$ as value of residual water content.

The graph of the relationship between the degree of saturation $(\mathrm{Sr})$ of peat soil and soil suction value in Fig. 8 shows some points of initial value of soil suction test, AEV value point, and residual water content. Based on the Fig. 8 results soil suction $\Psi=1.000 \mathrm{kPa}$ with $\mathrm{Sr}=142.5387 \%$ as the initial value of soil suction testing, $\Psi 1=6.63263 \mathrm{kPa}$ with $\mathrm{Sr} 1=141.1450 \%$ as $\mathrm{AEV}$ values, and $\Psi 2=16.7062$ $\mathrm{kPa}$ with $\mathrm{Sr} 2=137.6341 \%$ as residual water content.

Fig. 9 shows a graph of the relationship between volumetric water content $(\theta \mathrm{v})$ of peat soil and soil suction value. Fig. 9 shows some points of initial value of ground suction testing, Air Entry Value, and residual water content. The results is soil suction $\Psi=1 \mathrm{kPa}$ with $\theta \mathrm{v}=85.3882 \%$ as the initial value of soil suction testing, $\Psi 1=6.6326 \mathrm{kPa}$ with $\theta \mathrm{v} 1=78.9674 \%$ as $\mathrm{AEV}$ values, and $\Psi 2=16.7062 \mathrm{kPa}$ with $\theta \mathrm{v} 2=64.4148 \%$ as residual water content.

The relationship between soil suction clay with water content can be seen in Fig. 10. From the graph, it can be known that the starting point of the test on soil suction value $\Psi=1.0000 \mathrm{kPa}$ with a degree of saturation $\square=42.3292 \%$. While the soil suction value, $\Psi 1=48.9050 \mathrm{kPa}$ with $\square 1=$ $40.8399 \%$ shows the value point Air Entry Value and value $\Psi 2=103.5342 \mathrm{kPa}$ with $\square 2=37.9294 \%$ as residual water water content.
The result of the filter paper test on clay soil obtained the graph of soil saturation relationship with a degree of saturation (Fig. 11). From the graph, it can be seen the starting point of testing on soil suction value $\Psi=1.0000 \mathrm{kPa}$ with a degree of saturation, $\mathrm{Sr}=97.4560 \%$. While the soil suction value, $\Psi 1=48.9050 \mathrm{kPa}$ with $\mathrm{Sr} 1=93.6319 \%$ shows the point value of AEV (Air Entry Value) 103.5342 $\mathrm{kPa}$ with $\mathrm{Sr} 2=87.4753 \%$ residual water content. Fig. 12 illustrates the soil suction graph with volumetric water content. From the graph it can be seen the starting point of testing on soil suction value $\Psi=1.0000 \mathrm{kPa}$ with volumetric water content, $\Theta=56.7759 \%$. While the soil suction value, $\Psi 1=48.9045 \mathrm{kPa}$ with $\Theta 1=54.5481 \%$ shows the value point AEV (Air Entry Value) and value $\Psi 2=103.5342 \mathrm{kPa}$ with $\Theta 2=50.9613 \%$ as residual water content. The value of AEV (Air Entry Value) from [13] in the range 3kPa- 200 $\mathrm{kPa}$.

TABLE III

RESUlTS OF PEAT SOIL SUCTION FROM SAMPLE P1

\begin{tabular}{|c|c|c|c|c|}
\hline No. & $\begin{array}{c}\text { Water } \\
\text { Content } \\
(\boldsymbol{\omega}, \boldsymbol{\%})\end{array}$ & $\begin{array}{c}\text { Degree of } \\
\text { Saturation } \\
(\mathbf{S r}, \boldsymbol{\%})\end{array}$ & $\begin{array}{c}\text { Volumetric of } \\
\text { Water Content } \\
\left(\boldsymbol{\Theta}_{\mathbf{v}}, \boldsymbol{\%}\right)\end{array}$ & $\begin{array}{c}\text { Soil } \\
\text { Suction } \\
(\mathbf{\Psi}, \mathbf{k P a})\end{array}$ \\
\hline 1. & 149.4095 & 100.0000 & 85.3882 & 1.0000 \\
\hline 2. & 137.7388 & 99.9000 & 82.1750 & 3.8826 \\
\hline 3. & 127.0030 & 99.0000 & 78.9674 & 6,6326 \\
\hline 4. & 106.5902 & 95.8970 & 72.4620 & 7.7614 \\
\hline 5. & 97.3758 & 91.2470 & 68.9482 & 9.3663 \\
\hline 6. & 95.9804 & 90.1480 & 68.1180 & 10.0358 \\
\hline 7. & 91.3841 & 87.4720 & 66,0961 & 13.1782 \\
\hline 8. & 90.0128 & 86,4600 & 65,3315 & 13.4625 \\
\hline 9. & 87.9751 & 85.2470 & 64,4148 & 16.7063 \\
\hline 10. & 87.2716 & 84.1747 & 63.6042 & 23.9449 \\
\hline 11. & 85.8190 & 83.1140 & 62.8027 & 34.8745 \\
\hline 12. & 84.6429 & 82.2577 & 62.1556 & 55.5056 \\
\hline 13. & 84.3120 & 81.7230 & 61.7520 & 421.9588 \\
\hline 14. & 83.9462 & 81.1560 & 61.3232 & 798.5424 \\
\hline
\end{tabular}

TABLE IV

RESULTS OF CLAy SOIL SUCTION FROM SAMPLE P1

\begin{tabular}{|c|c|c|c|c|}
\hline No. & $\begin{array}{c}\text { Water } \\
\text { Content } \\
(\boldsymbol{\omega}, \boldsymbol{\%})\end{array}$ & $\begin{array}{c}\text { Degree of } \\
\text { Saturation } \\
(\mathbf{S r}, \boldsymbol{\%})\end{array}$ & $\begin{array}{c}\text { Volumetric of } \\
\text { Water Content } \\
\left(\mathbf{\Theta}_{\mathbf{v}}, \boldsymbol{\%}\right)\end{array}$ & $\begin{array}{c}\text { Soil } \\
\text { Suction } \\
(\mathbf{\Psi}, \mathbf{k P a})\end{array}$ \\
\hline 1. & 42.5407 & 100.0000 & 56.9463 & 1.0000 \\
\hline 2. & 41.9737 & 96,5143 & 56.2273 & 14.0080 \\
\hline 3. & 41.1994 & 94.6953 & 55.1676 & 19.7394 \\
\hline 4. & 40.4207 & 93.0846 & 54.2292 & 27.1052 \\
\hline 5. & 39.9430 & 91.7572 & 53.3172 & 31.5157 \\
\hline 6. & 39.0946 & 90.4190 & 52.6762 & 41.6312 \\
\hline 7. & 38.0377 & 88.4253 & 51.5148 & 49.9796 \\
\hline 8. & 37.3970 & 87.1340 & 50.7625 & 61.8733 \\
\hline 9. & 36.8482 & 85.9830 & 50.0920 & 129.2291 \\
\hline 10. & 36.4787 & 85.1767 & 49.6222 & 207.0814 \\
\hline
\end{tabular}




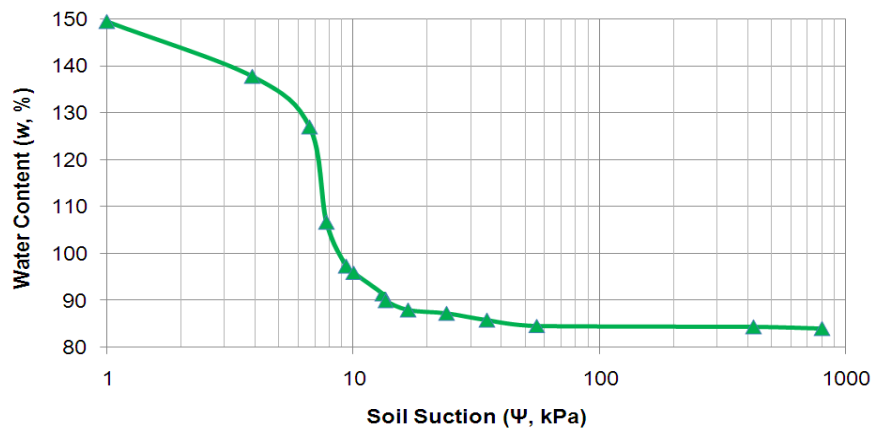

Fig. 7 Graph of water content versus peat soil suction from sample p1

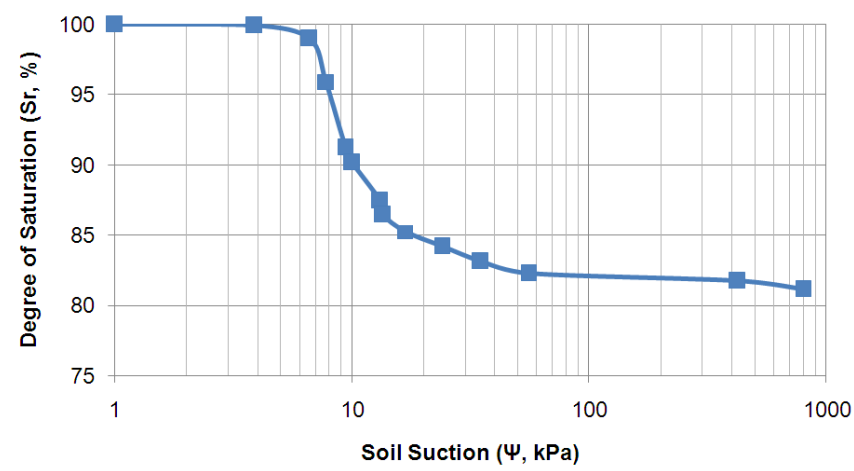

Fig. 8 Graph of degree of saturation versus peat soil suction from sample p1

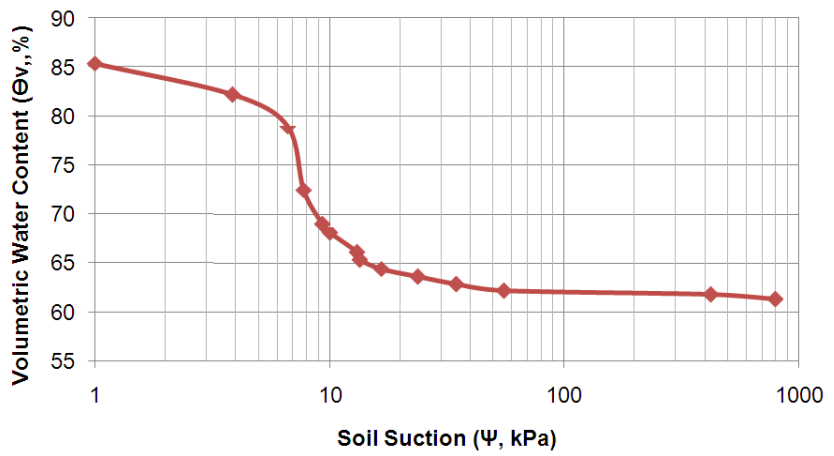

Fig. 9 Graph volumetric of water content versus peat soil suction from sample p1

As shown in the graph above shows that the value of water content indicated by the soil may affect the value of saturation degree and volumetric water content which will then also affect the value of suction produced by the tested peat soil. Each graph of the three samples shows three different points in each sample. The points on each graph show the amount of value at the beginning of the occurrence of soil suction, the value of the Air Entry Value, and the value of the value at the beginning of the residual water content.

The initial value of the occurrence of soil suction, the magnitude of the AEV value, and the value of the initial value of residual water content shown on the graph are the parameters that form the Soil Water Characteristic Curve(SWCC). The points that lie between the AEV point and starting point of the residual water content are the slope points of the moisture $(\square)$. The results of peat soil suction with a filter paper test method are shown in Table 5. Table 6 shows the results of clay soil suction. Fig. 12 and Fig.13 illustrate the graph of the relationship between Soil Water Characteristic Curve (SWCC) with peat soil and clay soil.

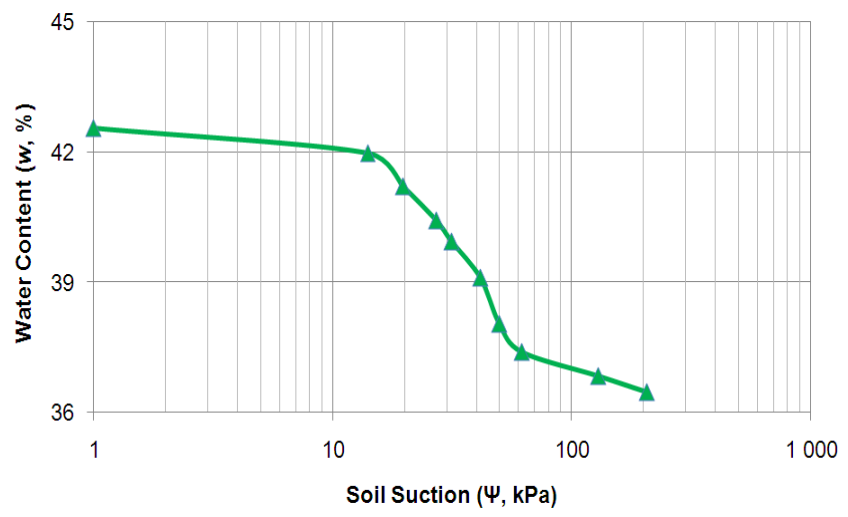

Fig. 10 Graph of water content versus clay soil suction from sample $\mathrm{c} 1$

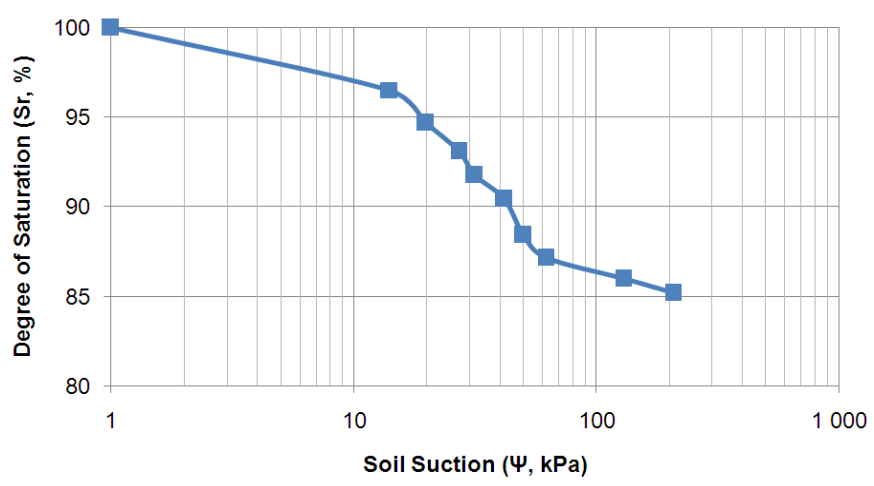

Fig. 11 graph of degree of saturation versus clay soil suction from sample c1

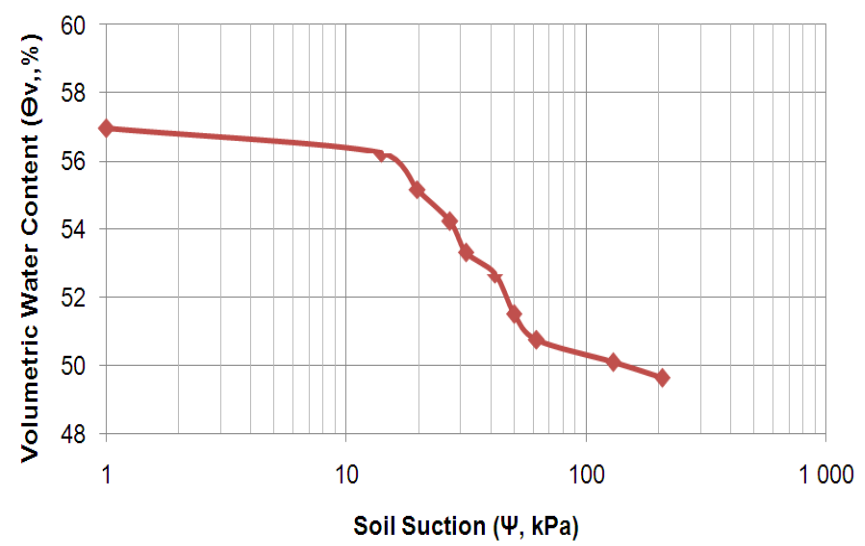

Fig. 12 Graph volumetric of water content versus clay soil suction from sample $\mathrm{c} 1$

Based on Table 5, the peat soil suction $(\Psi)$ values in the range of 3.2432-17.5230 $\mathrm{kPa}$. The clay soil suction $(\Psi)$ in Table 6 was in the range 61.8733-100.3421 kPa. In Fig. 13 and Fig. 14 it can be seen that SWCC is comparing the suction value of all peat soil and clay soil samples. Soil Water Characteristic Curve (SWCC) above shows the existence of parameters that influence it. The comparison of the Soil Water Characteristic Curve (SWCC) from Fig. 13 shows the amount of AEV (Air Entry Value) in each peat soil sample having a value of soil suction less than $20 \mathrm{kDa}$. Whereas based on Fig. 14 the value of AEV in each clay soil sample has a soil suction value of less than $110 \mathrm{kPa}$. 
In soil suction testing conducted with peat soil samples indicated that peat soil has a low suction to water with a soil suction value of no more than $1000 \mathrm{kPa}$. The clay has a relatively small percentage of pore volume. The amount of Pressure required on soil sucking is related to the pores of a land. The larger the pores of the soil, the pressure required to suction the water gets smaller because the soil that has a larger pore can be easier in passing water. The research of [12] describes the matrix suction of 10 and $500 \mathrm{kPa}$ on coarse-grained soils and fine-grained soils. The results show that the Grained soils and fine-grained soils. The results show that the sensitivity analysis obtained a good SWCC curve.

TABLE V

Results of PeAt Soll Suction with Filter PAPER Method

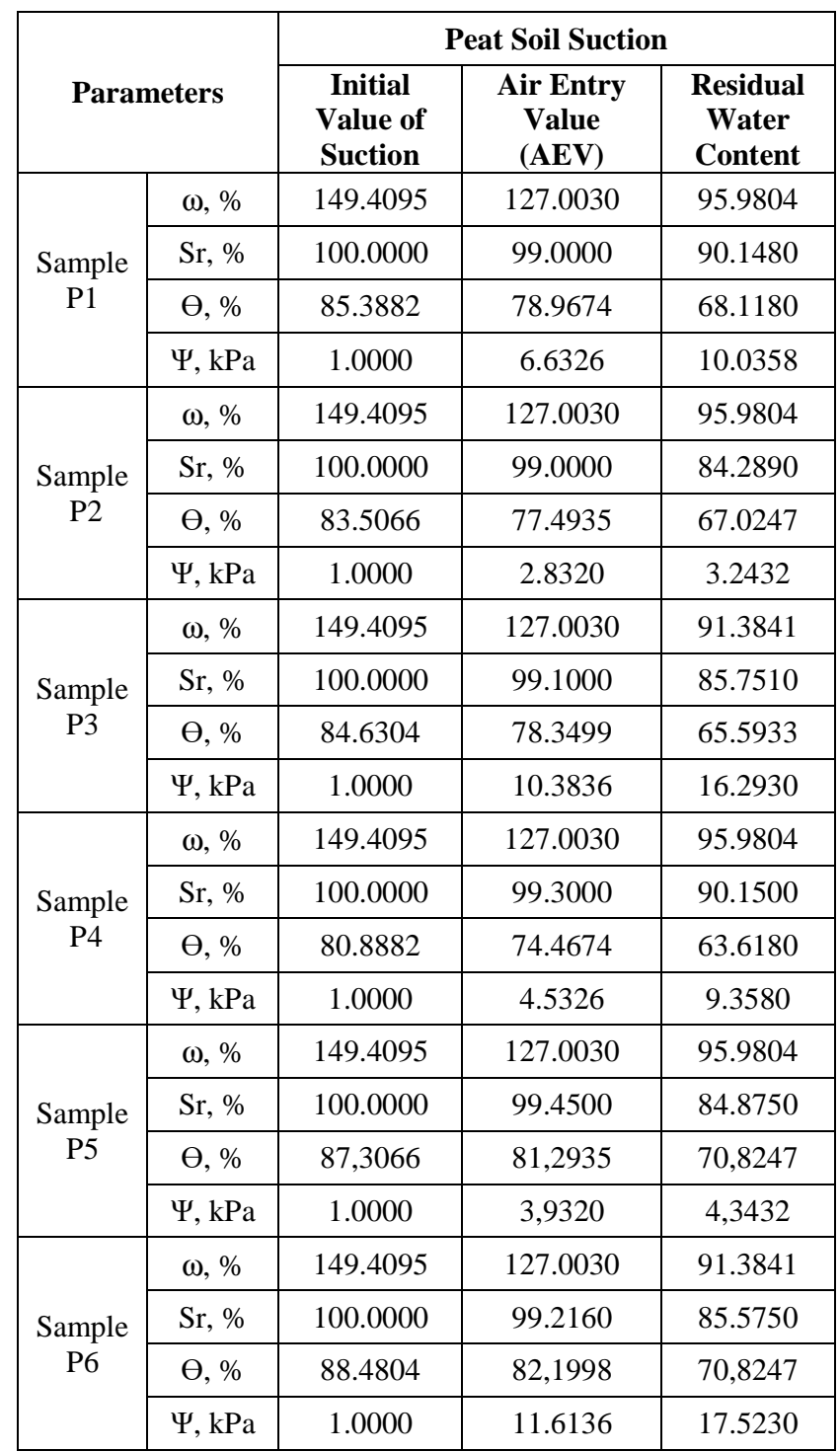

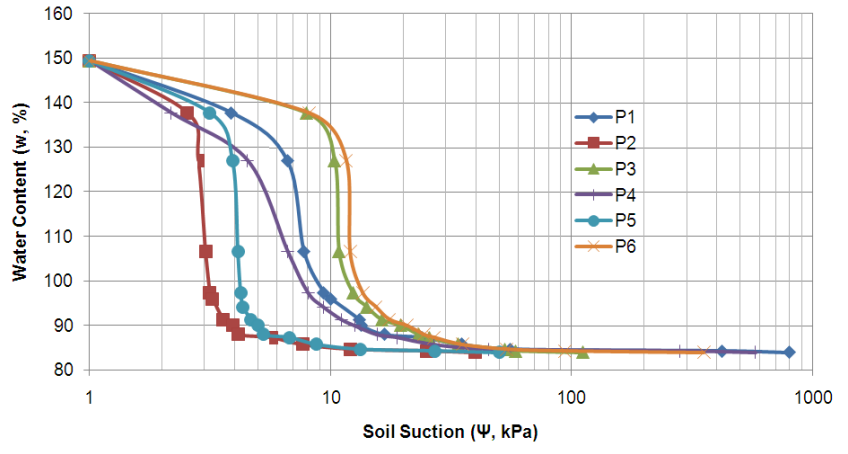

Fig. 13 Soil water characteristic curve (swcc) peat soil suction

TABLE VI

RESUlts of Clay SOIL Suction with FILTER PAPER Method

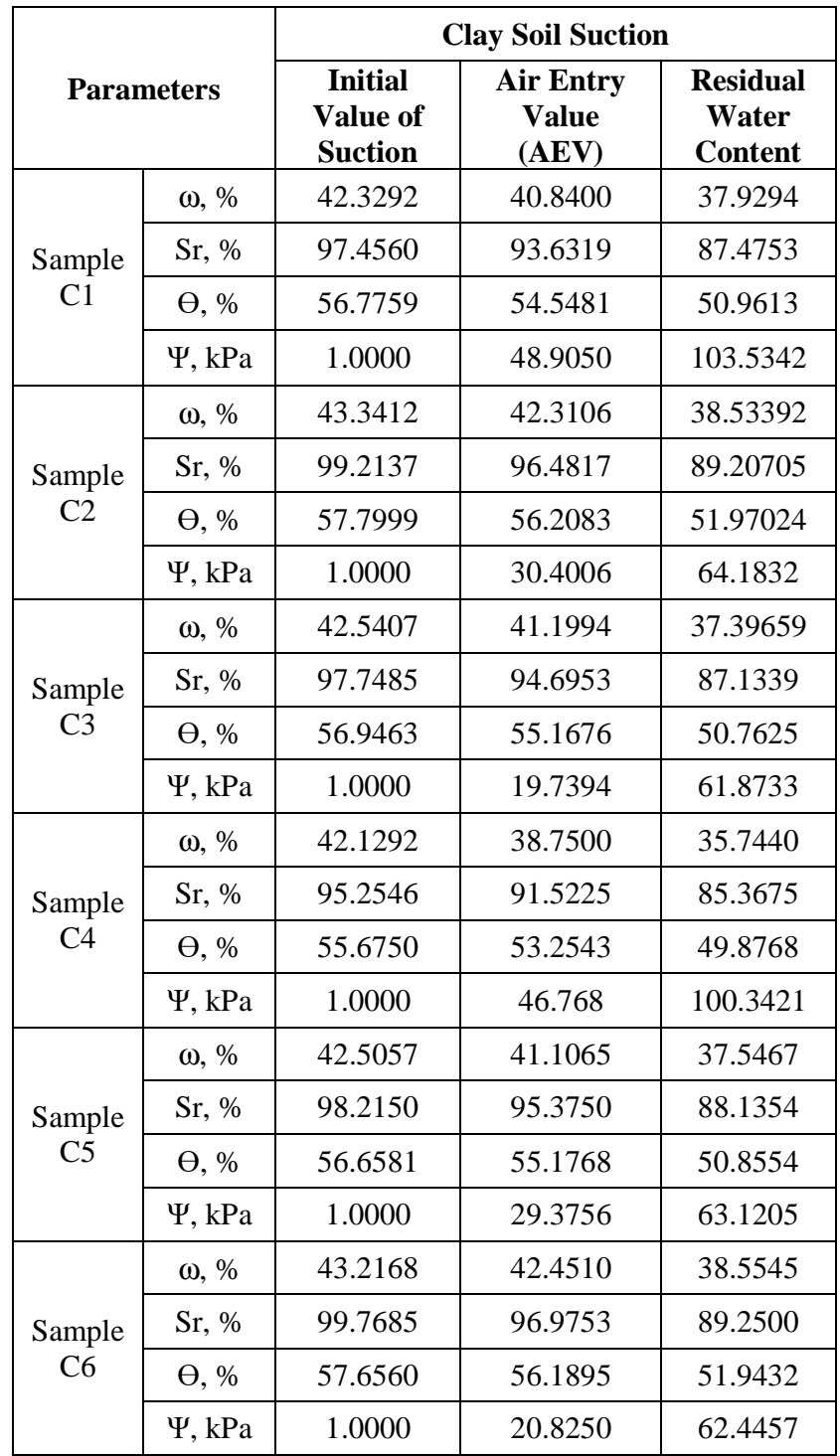




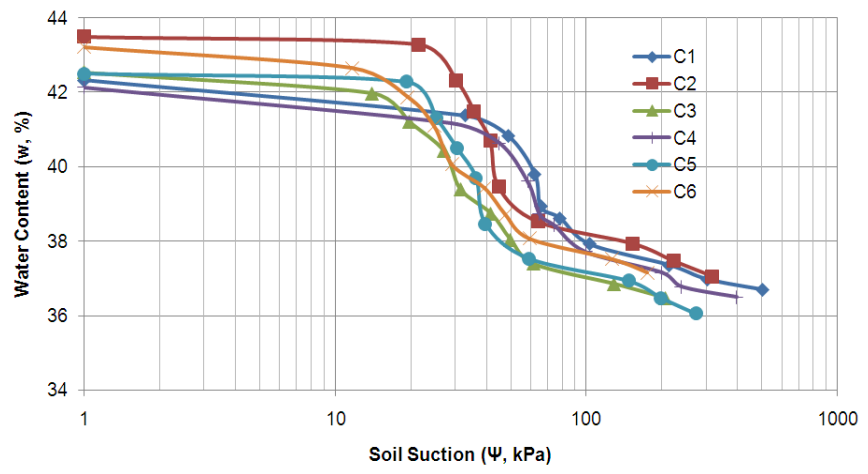

Fig. 14 Soil water characteristic curve (swcc) clay soil suction

Based on the soil suction capability generated in soil suction testing, it is found that the greater the value of water content of a soil type, the greater the degree of saturation and volumetric moisture value of the soil type. Conversely, the water content of land will affect the absorption or puffing of the soil with the higher the value of moisture content, a degree of saturation, and volumetric water content of the soil will be smaller the value of suction produced by the soil. So from the results of research that has been done can be concluded that clay soil has a high soil suction ability compared with the suction be possessed by peat soil.

\section{CONCLUSION}

The value of water content $(\omega)$ from peat soil is $294.30 \%$. The $\mathrm{pH}$ value of peat soil is 3.00. Peat soils are included on the $\mathrm{H} 4$ from Von Post classification. So, peat soils are classified as fibrous peat soils. The value of peat soil suction

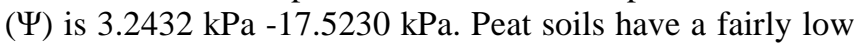
suction capability. This is because the amount of soil suction value $(\Psi)$ on peat soil obtained from the suction test with paper test does not reach more than $1000 \mathrm{kPa}$. The water content of clay soil is $62.05 \%$. pH value about 5.00 . Classification of clay soils based on AASHTO is A-7-5. Moreover, based USCS is $\mathrm{OH}$ (organic clay). The value of peat soil suction $(\Psi)=61.8733 \mathrm{kPa}-100.3421 \mathrm{kPa}$.

\section{ACKNOWLEDGMENT}

The author would like to thank Lily Triani and Ade Marshella. This research is part of the Dissertation research from Faculty of Engineering, Universitas Sriwijaya.

\section{REFERENCES}

[1] ASTM International. Standard Test Method for Measurement of Soil Potential (Suction) Using Filter Paper, D5298-03. ASTM International. 2003.

[2] Leong, E., C., Kizzam, R., and Rahardjo, H., Measurement of Soil Suction using Moist Filter Paper. E3S W. UNSAT 10012. DOI: 10.1051/ e3sconf/20160910012. 2016.

[3] Hezmi, M.a., Saari, R., Zahari, M., Z., Abdullah, R., A., Yunus, N., Z., M., and Safuan, Rashid, A., S., A., Soil Water Characteristic Curves of Compacted Kaolin for Various Initial Moisture Content. Jurnal Teknologi (Sciences and Engineering) 76:2 (2015) 39.44.

[4] Leong, E., C., He, L., and Rahardjo, H., Factors Affecting the Filter Paper Method for Total and Matric Suction Measurements. Journal Geotechnical Testing, Vol. 25, No. 3. Paper ID GTJ20028198_253. 2002.

[5] J. A. Munoz-Castelblanco, Jean-Michel Pereira, Pierre Delage, YuJun Cui. Suction measurements on a Natural Unsaturated Soil: A Reappraisal of the Filter Paper Method. Alonso, E. E., and Gens, A. Unsaturated Soils-Proc. Fifth Int. Conf. on Unsaturated Soils, Sep 2010, Barcelona, Spain. CRC Press, 1, pp.707-712, 2010.

[6] Fredlund, D., G., Rahardjo, H., and Fredlund, M., D., Unsaturated Soil Mechanics in Engineering Practice. John Wiley and Sons. Canada. 2012.

[7] Zhai, Q., and Rahardjo, H., Determination of Soil Water Characteristic Curve Variables. Computers and Geotechnics 42 (2012) 37-43.

[8] Kheng, B., C., Leong, E., C., and Rahardjo, H., A Simplified Method to Estimate The Soil Water Characteristics Curve. Canadian Geotechnical Journal. 47: 1382-1400. doi:10.1139/T10-033. 2010.

[9] Sutejo, Y. et al., Engineering Properties of Peat in Ogan Ilir Regency. Jurnal Teknologi (Sciences and Engineering) 78: 7-3. 61-69. 2016

[10] Nevia. The response of Rice and Carbon Emission to Application of Ameliorant Dregs in The Peat Soil With Saturation and Unsaturation Condition International. Journal on Advanced Science, Engineering And Information Technology (IJASEIT), Vol.4 No. 6 ISSN: 20885334. 2014.

[11] Bow, Y., Hairul, and Hajar, I., Molecularly Imprinted Polymer (MIP) Based PVC-Membrane-Coated Graphite Electrode for the Determination of Heavy Metals. Journal on Advanced Science, Engineering and Information Technology (IJASEIT), Vol.5. No. 6 ISSN: 2088-5334. 2015.

[12] Satyanaga, A., Rahardjo, H., Leong, E., C., and Wangm, J., Y., Water Characteristics Curve of Soil with Bimodal Grain Size Distribution. Computers and Geotechnics 48. 51-61. 2013.

[13] Lins, Y., Schanz, T., and Fredlund, D., G., Modified Pressure Plate Apparatus and Column Testing Device for Measuring SWCC of Sand. Geotechnical Testing Journal, Vol. 32, No. 5. Paper ID GTJ101318. 2009. 